\title{
Correction: Construction and verification of the transcriptional regulatory response network of Streptococcus mutans upon treatment with the biofilm inhibitor carolacton
}

Padhmanand Sudhakar ${ }^{1 \dagger}$, Michael Reck ${ }^{2 \dagger}$, Wei Wang ${ }^{1}$, Feng Q He ${ }^{3}$, Irene Wagner-Döbler ${ }^{2^{*}}$ and An-Ping Zeng ${ }^{1 *}$

\section{Correction}

After publication of the original article [1] it came to the publishers attention that one name had been inadvertently misspelt. The correct authors' list should read as indicated above. We apologize for any inconvenience this has caused.

\begin{abstract}
Author details
'Institute of Bioprocess and Biosystems Engineering, Hamburg University of Technology, 21073 Hamburg, Germany. ${ }^{2}$ Research Group Microbial

Communication, Helmholtz Center for Infection Research, Inhoffenstrasse 7, 38124 Braunschweig, Germany. ${ }^{3}$ Luxembourg Centre for Systems

Biomedicine, 7, Avenue des Hauts Fourneaux, L-4362 Belval, Luxembourg.
\end{abstract}

Received: 14 August 2014 Accepted: 14 August 2014

Published: 29 August 2014

\section{Reference}

1. Sudhakar P, Reck M, Wang W, He FQ, Dobler IW, Zeng AP: Construction and verification of the transcriptional regulatory response network of Streptococcus mutans upon treatment with the biofilm inhibitor carolacton. BMC Genomics 2014, 15:362.

\section{doi:10.1186/1471-2164-15-739}

Cite this article as: Sudhakar et al:: Correction: Construction and

verification of the transcriptional regulatory response network of

Streptococcus mutans upon treatment with the biofilm inhibitor

carolacton. BMC Genomics 2014 15:739.

\footnotetext{
*Correspondence: iwd@helmholtz-hzi.de; aze@tuhh.de ${ }^{\dagger}$ Equal contributors

${ }^{2}$ Research Group Microbial Communication, Helmholtz Center for Infection Research, Inhoffenstrasse 7, 38124 Braunschweig, Germany

'Institute of Bioprocess and Biosystems Engineering, Hamburg University of Technology, 21073 Hamburg, Germany
}

Submit your next manuscript to BioMed Central and take full advantage of:

- Convenient online submission

- Thorough peer review

- No space constraints or color figure charges

- Immediate publication on acceptance

- Inclusion in PubMed, CAS, Scopus and Google Scholar

- Research which is freely available for redistribution

\section{Ciomed Central}

